\title{
THE RUSSIAN SETTLEMENT AT RUSSEKEILA AND LAND RISE IN VESTSPITSBERGEN*
}

\author{
Hans Christiansson $\uparrow$
}

Introduction

$\mathbf{T}$

THE archeological-ethnographical expeditions to Vestspitsbergen in the summers of 1955 and 1960 were undertaken in order to investigate the possibility of settlements having existed in Spitsbergen before 1596, when the islands were "officially" discovered by the Dutch explorer Barents, and to search for traces of the many whaling and hunting stations that existed from the 17th to the 19th century (Conway 1906).

These inter-Nordic expeditions were organized by the writer, who also led the expeditions in the field, in 1955 together with P. Simonsen of Troms $\phi$, Norway. Both expeditions were sponsored by the Troms $\varnothing$ Museum, and all collections have been deposited there. Preliminary reports of the 1955 expedition have been made by Christiansson (1956) and Simonsen (1957), and the reader is also referred to the reports in the "Polar Record" (1957, 1961). Shaskol'skiy (1958) has discussed the 1955 expedition from the Russian ethnographical point of view.

No detailed investigations of the many hunting stations have been made earlier, although isolated huts in Spitsbergen have often been mentioned and in a few cases described in the literature (e.g., Carlheim-Gyllensköld 1900 , Norberg 1918). In connection with the main work of the expeditions some observations were made concerning the problem of land rise after deglaciation, and it is these observations that are the primary concern of the present report.

\section{Excavations at Russekeila}

Most of the work of the expeditions was carried out at Russekeila, an old Russian hunting station situated 3.5 kilometres northeast of Kapp Linné and about 100 metres east of the mouth of Linnéelva, on the south shore of Isfjorden (Figs. 1, 2, and 3). The excavations were made during July and August, 1955 and 1960, and many hunting implements, chess men, skinning tools, lamps, clay vessels, and barrel-making equipment were found, plus fine examples of handicraft in the form of carvings.

* Translated from the Swedish by W. Blake, Jr.

$\dagger$ Museum för Nordiska Fornsaker, Uppsala Universitet, Uppsala, Sweden. 
Among the objects in the ruins at Russekeila was a board with the date 1786 and some Russian letters carved on it, as well as a roof timber with the date 1778. Thus the ruins are known to date from the later part of the 18th century. It is probable, however, that the hunting station was there earlier, as no less than four different culture layers could be distinguished. The wood bearing the dates came from the uppermost layer, but there appear to be no great age differences between the four layers.

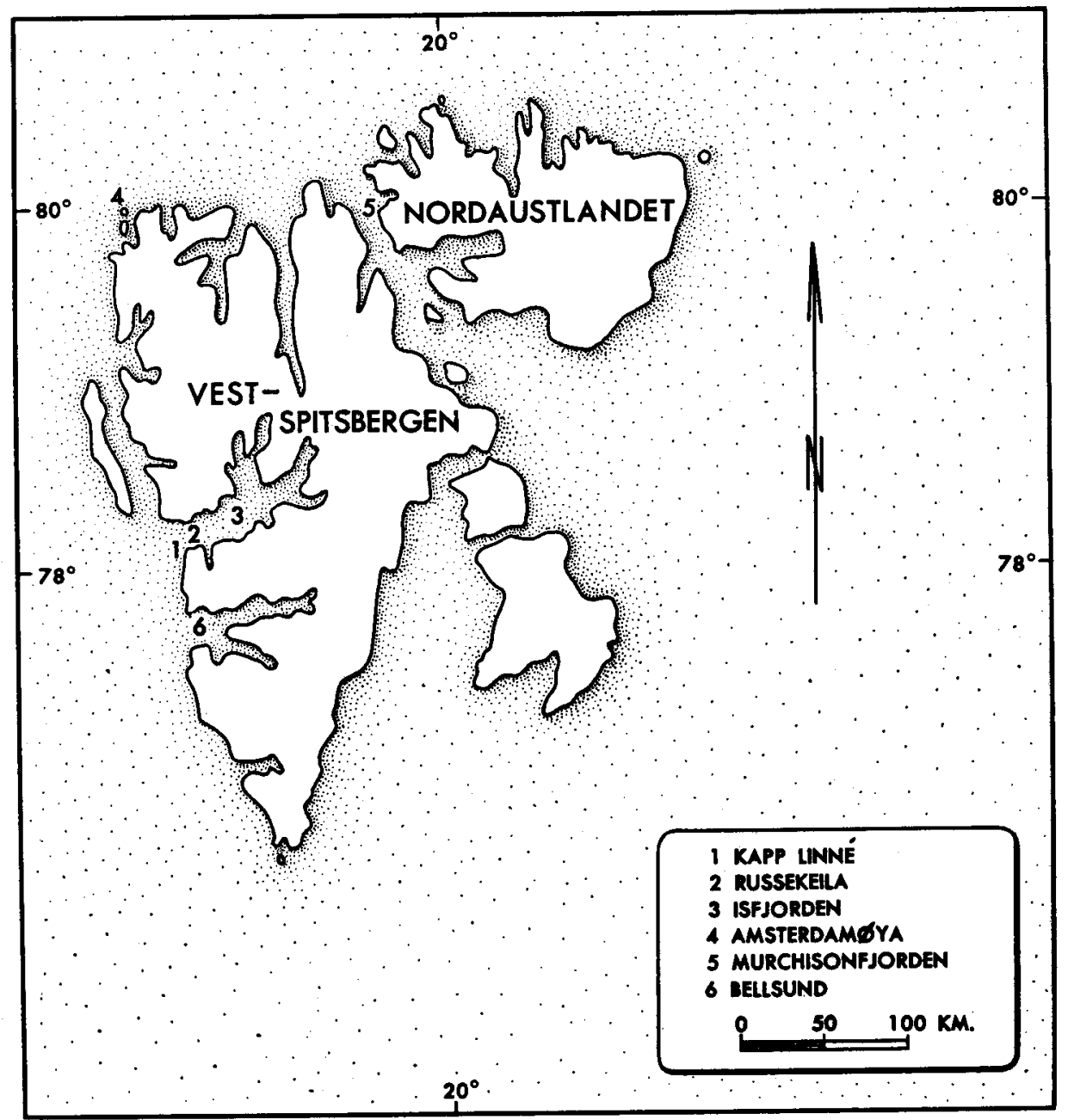

Fig. 1. Spitsbergen. (Base map by Orvin, 1940).

The Russekeila ruins lie near the edge of a flat vegetation-covered terrace, one of a series of gently sloping raised beaches (Figs. 2 and 3). The ruins are about 7 metres above sea-level at high tide according to observations made in August 1955 and August 1960, and the terrace edge slopes 
steeply down toward a coarse gravel beach at the shore. On the side of the ruins facing Isfjorden there is a large kitchen midden. This is partly spread out on the surface of the terrace directly in front of the ruins, but most of it lies on the 4- to 5-metre-high steep slope of the terrace facing the shore. This midden has a maximum thickness of about 1 metre and is 30 metres wide near the top of the steep slope; at the foot of this slope it is only a few centimetres thick and about 6 metres wide (Figs. 3, 4, and 5).

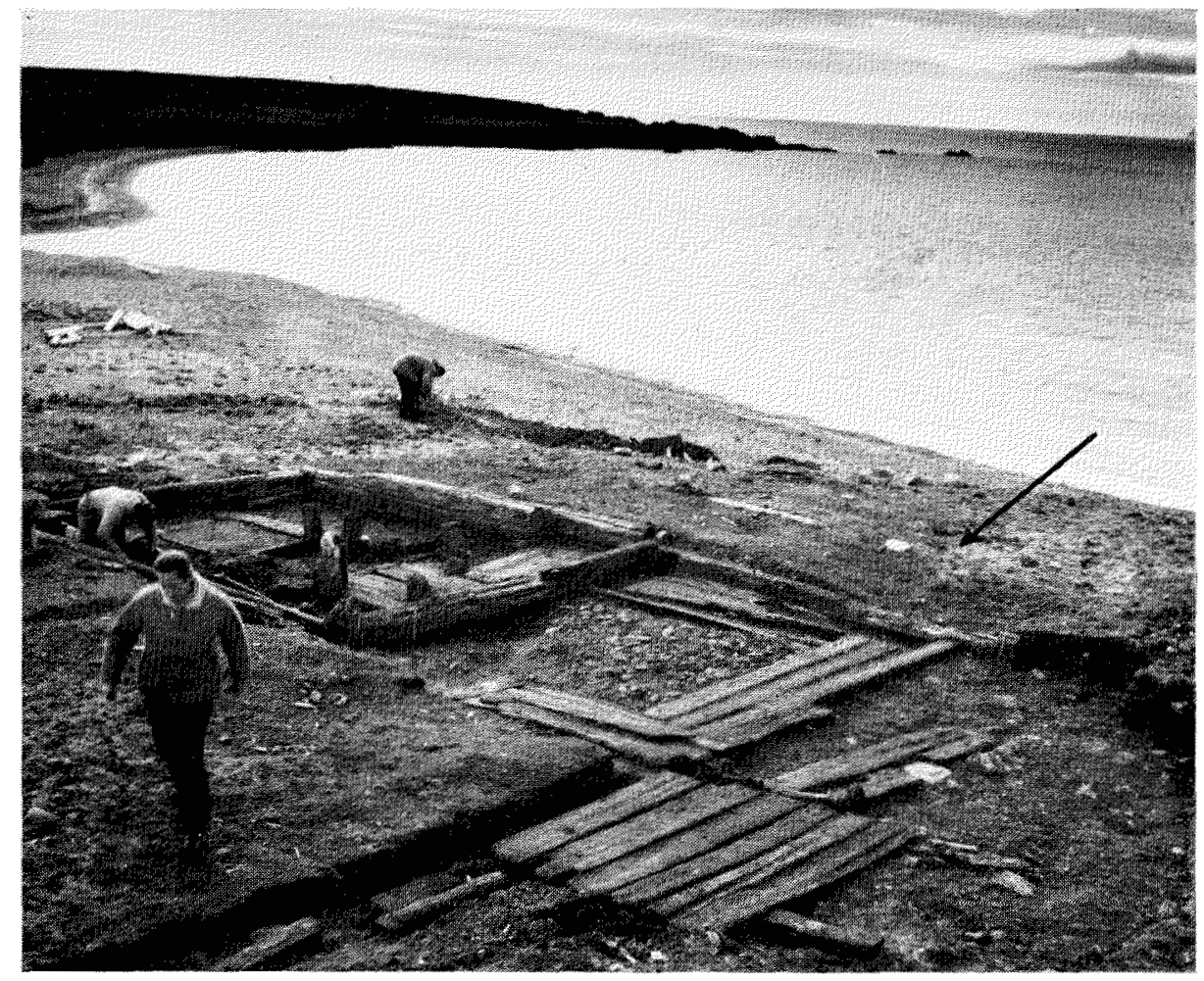

Fig. 2. Detail of the ruins at Russekeila. Note kitchen midden (arrow) in front of the excavated Russian hut. View west.

The kitchen midden extends down so far that the water at high tide lies only 15 to 17 metres from its foot and 2 metres below it. The highest of the recent "storm beaches," in reality probably a result of sea ice shove, extends 1 to 2 metres up over the foot of the kitchen midden, covering it with a 30-centimetre-thick layer of gravel and cobbles.

As the Russians were not particularly active in this part of Spitsbergen much after 1826 and the last Russian expedition visited the islands in 1851-52 (Conway 1906, pp. 272, 275), it is probable that the kitchen midden has been undisturbed for over 100 years. The luxurious moss cover that has 
overgrown the midden also indicates that it has not been added to for a long time, as such a moss cover takes a considerable time to develop. Rapp (1957, pp. 194-5) has shown, by comparing pictures taken in 1906 and 1954, that vegetation of the same type has not changed appreciably in nearly 50 years in the inner part of Isfjorden.

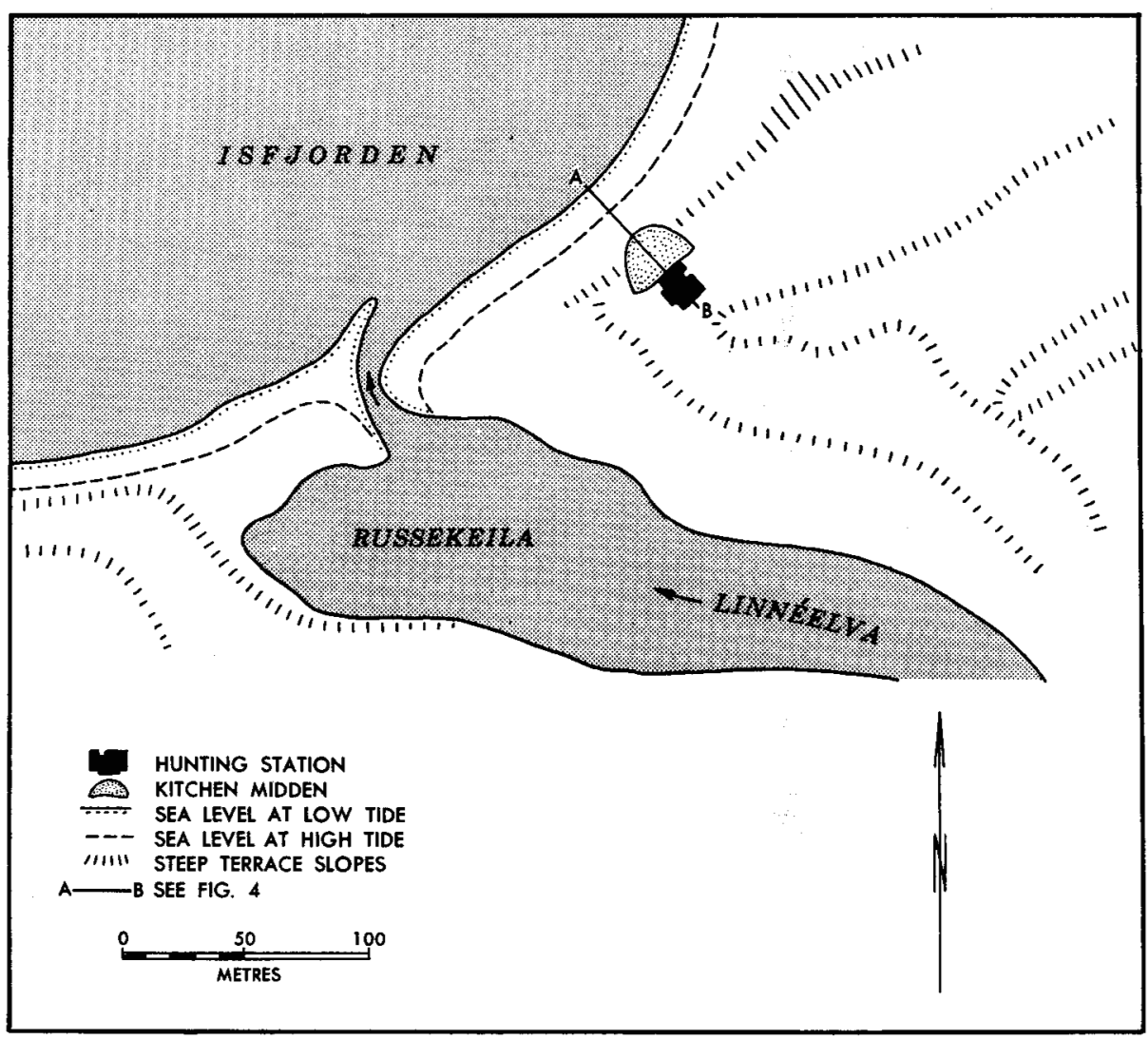

Fig. 3. Russekeila, Isfjorden. (Based on a map by H. Christiansson and P. Simonsen, August 1955).

\section{Land rise}

Since the kitchen midden is situated so that its undisturbed foot is only 15 to 17 metres from the sea and 2 metres above high-tide level, it is hardly possible that the land has risen appreciably in the last century. Birkenmajer $(1960$, p. 290) has suggested that the uplift in this area is approximately 2 metres per century, and if this were correct the foot of the kitchen midden would have been washed away by storm waves. However, the presence of 
fresh, non-rounded bricks and unbroken bird bones in the lower part of the kitchen midden indicates that it has not been subject to wave action. Nor does the midden appear to have moved downhill through solifluction because (1) it is a very compact mass containing many artifacts, (2) it has a thick cover of moss, and (3) it is thicker at the top of the slope than at the bottom. Indeed, rather than a land rise it is more likely that a very slight sinking of the land has occurred since the end of the 18th century, but the evidence at present is inconclusive.

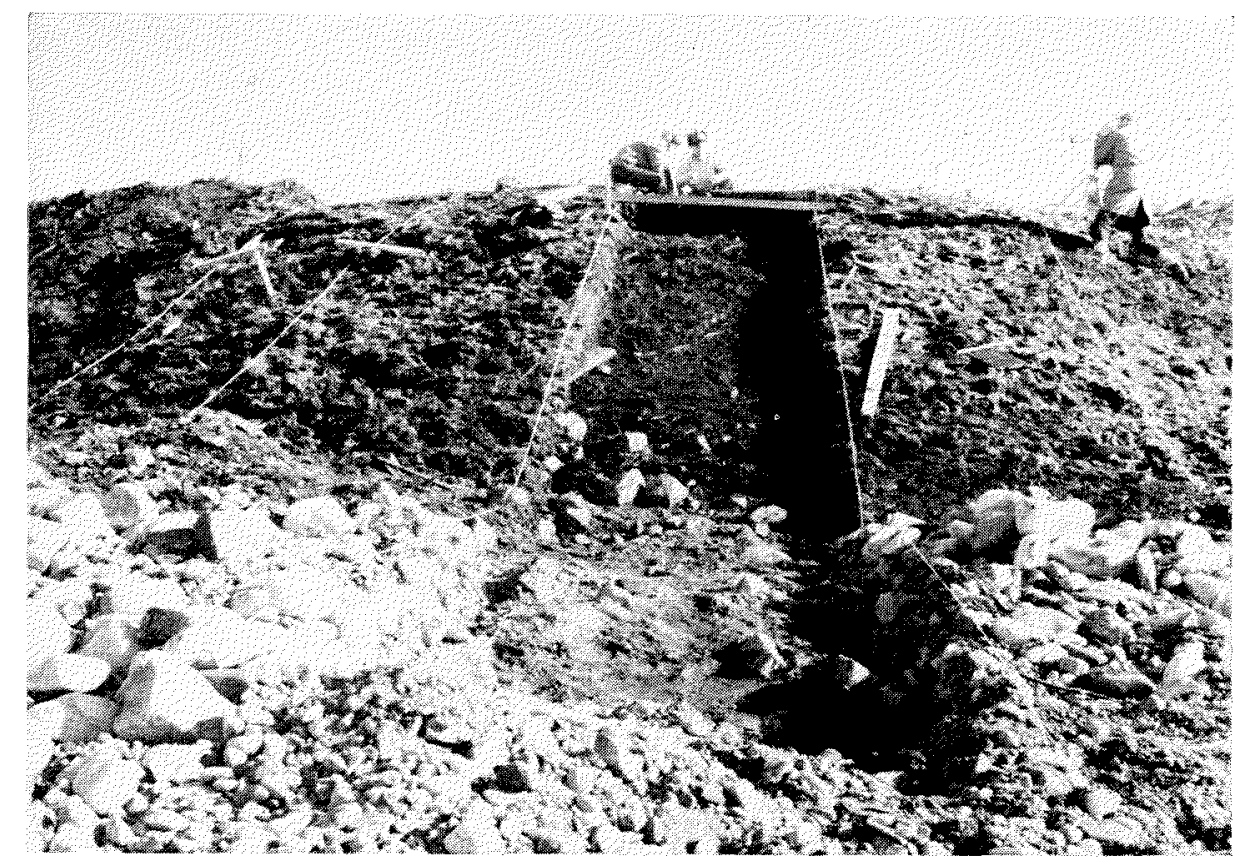

Fig. 4. The kitchen midden as seen from the shore (A-B, Fig. 3). In the foreground beach material covers the foot of the midden.

Similar evidence against a rise of the land is present in the northwest corner of Vestspitsbergen. In several places there are ovens for cooking whale blubber that were built by the Dutch in the 17th century. Vogt (1932, p. 563) postulated a sinking of the land because some of the ovens are now being washed into the sea, but more recently Feyling-Hanssen $(1954$, pp. 76-97) suggested that this apparent sinking was only due to erosion of the shore. However, as Feyling-Hanssen's detailed profiles show, many of the ovens are now only 1 metre above sea-level. They could not have been built any lower, and even if a sinking of the land may not have taken place, at least there has been no uplift in the last 300 to 350 years.

It is probable that archeological investigations in Spitsbergen, which are planned as a long term project and which, it is hoped, will include 
radiocarbon dating of material from different old settlements, will provide more details concerning the postglacial emergence of the land. Although there are not yet enough data to show that the entire Spitsbergen region has behaved in the same way isostatically during the last few hundred years, the evidence from the Russian hut in Murchisonfjorden (Blake 1961), from the whale oil ovens on Amsterdam $\varnothing$ ya and elsewhere in northwestern Vestspitsbergen, and from the Russian settlement at Russekeila in Isfjorden is the same. In these areas there has been no appreciable land rise in at least 100 years, and on Amsterdamøya at least, no significant change in the relation between land and sea has occurred for over three centuries.

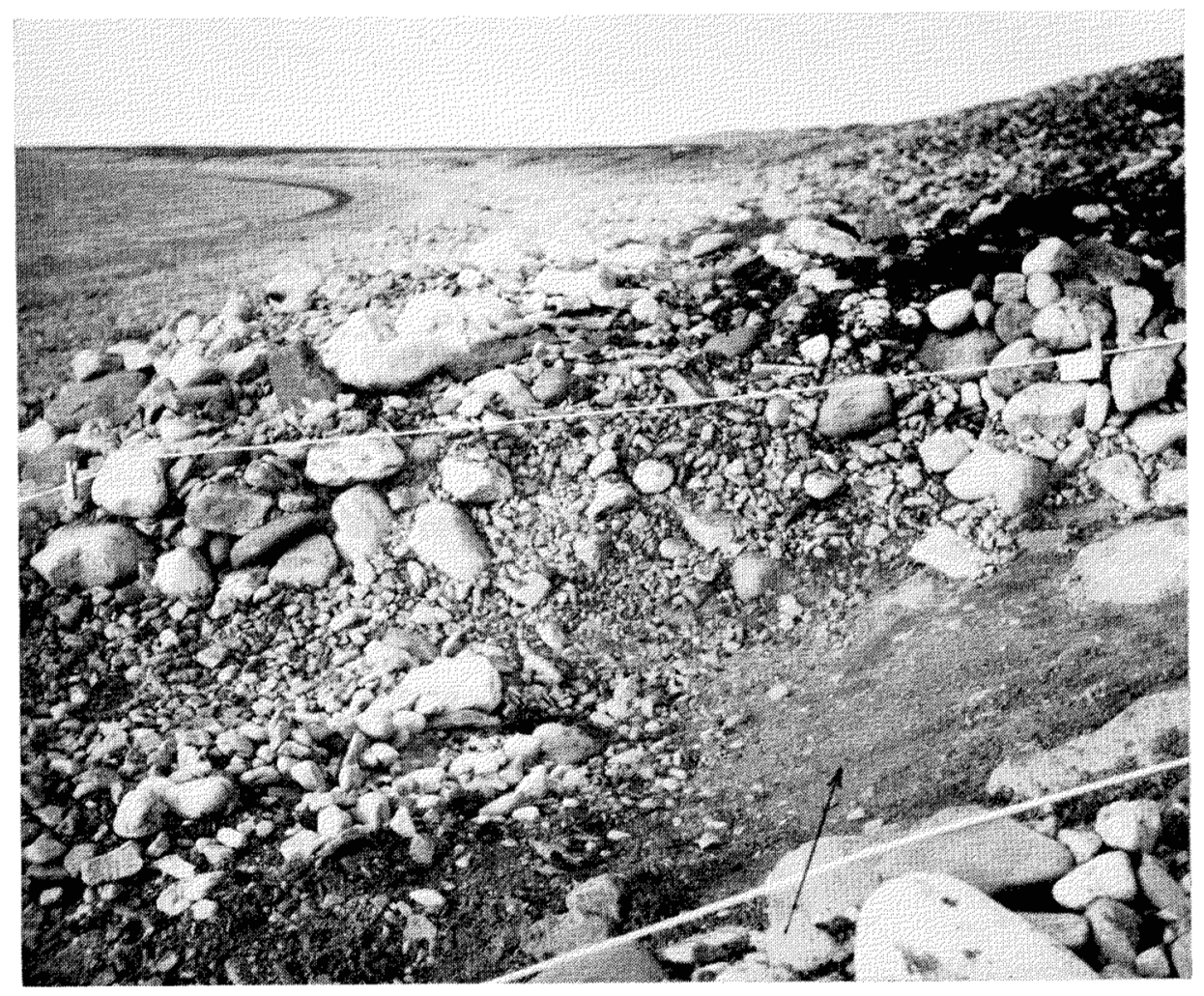

Fig. 5. View northeast along the shore of Isfjorden. In the foreground (arrow) the lowest part of the kitchen midden is overlain by beach material.

\section{Acknowledgments}

The writer expresses his thanks to all members of both expeditions for assistance in the field, especially M. Müller-Wille, P. Manecke, and L. Florin for the excavation of the kitchen midden and mapping during the summer of 1960. Financial support for the expeditions was generously 
provided by: (1) from Norway - Norges Almenvitenskapelige Forskningsråd; (2) from Sweden - Statens Humanistiska Forskningsråd, Längmanska Kulturfonden, and Letterstedtska Föreningen; and (3) from Finland Nordenskiöldsamfundet. Norsk Polarinstitutt and Troms $\varnothing$ Museum helped the expeditions in many ways, and a number of private firms kindly donated food and equipment. Appreciation is expressed to W. Blake, Jr. for undertaking the translation and for critical reading and discussion.

\section{References}

Birkenmajer, K. 1960. Recent vertical movements of Spitsbergen. Internat. Geol. Congress, Rept. of the 21st Session, Norden (Copenhagen), Proc. Part 21:281-94.

Blake, W. Jr. 1961. Russian settlement and land rise in Nordaustlandet, Spitsbergen, Arctic 14:101-11.

Carlheim-Gyllensköld, V. 1900. På åttionde breddgraden. Stockholm: A. Bonnier, 256 pp.

Christiansson, H. 1956. Den kulturhistoriska expeditionen till Spetsbergen 1955. Fornvännen 51:286-9.

1961. Scandinavian archeological and Quaternary geology expedition to Spitsbergen, 1960. Polar Record 10, No. 68:516-7.

Christiansson, H., and Simonsen, P. 1957. Scandinavian archeological expedition to Spitsbergen. Polar Record 8, No. 55:348-9.

Conway, W. M. 1906. No man's land. Cambridge: University Press, 377 pp.

Feyling-Hanssen, R. W. 1954. De gamle trankokerier på Vestspitsbergens nordvesthjørne og den formodede senkning av landet i ny tid. Norsk Geografisk Tidsskr. 13:76-98. (Also reprinted as Norsk Polarinstitutt Medd. 77:76-98, 1954).

Norberg, H. L. 1915-16. Om Spitsbergens kolonisation i ældre tider. Troms $\varnothing$ Museums Aarshefter 38-39:65-74.

Orvin, A. K. 1940. Outline of the geological history of Spitsbergen. Skrifter om Svalbard og Ishavet 78:1-57.

Rapp, A. 1957. Studien über Schutthalden in Lappland und auf Spitzbergen. Zeit. für Geomorphologie 1:179-200. (Reprinted as Medd. från Uppsala Universitets Geografiska Institution, Ser. A, No. 121:179-200, 1957).

Shaskol'skiy, I. P. 1958. Skandinavskaya ekspeditsiya 1955 g. na Shpitsbergen (otkry tiye ostatkov stanovishcha russkikh pomorov XVIII v.). Sovetskaya Etnografiya Nr. $4: 95 \mathrm{ff}$.

Simonsen, P. 1957. Fra den første arkeologiske Svalbard-ekspedisjons arbeid. Polarboken 1957:76-84.

Vogt, T. 1932. Landets senkning i nutiden på Spitsbergen og $\emptyset_{\text {st-Grønland. Norsk }}$ Geologisk Tidsskr. 12:563-74. (Reprinted as Norges Svalbard- og Ishavs-Unders $\varnothing k e l s e r$ Medd. 15:563-74, 1932). 